\title{
Structural stability, hardness, fracture toughness and melting points of Ta1-xHfXC and Ta1-xZrxC ceramics from first-principles
}

\section{Shuoxin Zhang}

Tianjin Normal University

Shiyu Liu ( $\nabla$ buaasyliu@gmail.com )

Tianjin Normal University

Dali Yan

Tianjin Normal University

Qian Yu

Tianjin Normal University

\section{Haitao Ren}

Tianjin Normal University

\section{Bin Yu}

Tianjin Normal University

Dejun Li ( $\nabla$ dejunli@mail.tjnu.edu.cn )

Tianjin Normal University

\section{Research Article}

Keywords: Ta1-xHfxC, Ta1-xZrxC, fracture toughness, melting points, first-principles

Posted Date: March 25th, 2020

DOl: https://doi.org/10.21203/rs.3.rs-19083/v1

License: (9) This work is licensed under a Creative Commons Attribution 4.0 International License. Read Full License 


\section{Abstract}

We systematic investigated the influence of substitution of $\mathrm{Hf}$ and $\mathrm{Zr}$ atoms for Ta atoms in $\mathrm{TaC}$ using first-principles supercell (SC) method and virtual crystal approximation (VCA) methods, including the impurity formation energy, lattice constant, volume, elastic constants, elastic moduli, melting points, fracture toughness and density of states of the Ta 1-x Hfx C and Ta1-x Zrx C ceramics in the whole range of content $0 \leq x \leq 1$. Our calculated results show that the stability of Ta 1-x $\mathrm{Hf} x \mathrm{C}$ and Ta 1-x Zrx C increases with the increase of $\mathrm{Hf}$ and $\mathrm{Zr}$ content, and Ta1-x Zrx C is more stable than Ta1-x Hfx C at the same content of $\mathrm{Hf}$ and $\mathrm{Zr}$. The lattice constants and volumes dilate with the increase of $\mathrm{Hf}$ and $\mathrm{Zr}$ content. Furthermore, Ta1-x Hfx C and Ta1-x Zrx C carbides are mechanically stable and brittle. The bulk modulus of Ta1-x Hfx C and Ta1-x Zrx C decreases with the increasing content of $\mathrm{Hf}$ and $\mathrm{Zr}$. Moreover, the hardness, fracture toughness, and melting point of Ta1-x $\mathrm{Hf} \times \mathrm{C}$ and Ta1-x Zrx C solid solutions have the peak. In particular, Ta0.8Hf0.2C has the highest hardness, largest fracture toughness and highest melting temperature.

\section{Introduction}

Transition metal carbides $\mathrm{TaC}, \mathrm{HfC}$ and $\mathrm{ZrC}$, are the most promising candidates for ultra-high temperature ceramic (UHTC) materials for the aerospace industry. They not only have extremely high melting temperature, high hardness, high modulus, high electrical conductivity, corrosion resistance and excellent chemical stability, but also have strong covalent bonds and low self-diffusion coefficients [1-5]. But this also makes them difficult to sinter. Their hardness can be maintained at very high temperatures, and they have low chemical reactivity, oxidation resistance and fracture toughness [6-9]. The combination of these superior properties largely depends on the chemical composition and microstructure state [10] due to severe carbide growth and harsh sintering conditions, it is often necessary to achieve full densification, which instead reduces the performance of the material [11].

In order to solve the deterioration of the properties of transition metal carbides, various technologies have been present. However, these technologies are not adequate to comply full densification at relatively low temperatures $\left(<2000^{\circ} \mathrm{C}\right)$, and they are susceptible to oxygen pollution during synthesis, which may be detrimental to densification and property [12]. Therefore, recently, $\mathrm{Ta}_{1-\mathrm{x}} \mathrm{Hf}_{\mathrm{x}} \mathrm{C}$ and $\mathrm{Ta}_{1-\mathrm{x}} \mathrm{Zr}_{\mathrm{x}} \mathrm{C}$ solid solution ceramics have attracted much attention because their melting temperatures are forecast to exceed $\mathrm{TaC}$, $\mathrm{HfC}, \mathrm{ZrC}$ and the formation of $\mathrm{Ta}_{1-\mathrm{x}} \mathrm{Hf}_{\mathrm{x}} \mathrm{C}$ and $\mathrm{Ta}_{1-\mathrm{x}} \mathrm{Zr}_{\mathrm{x}} \mathrm{C}$ ceramics could effectively improve their materials and densification properties [13-15]. But the most recent researches have mainly focused on Ta-rich TaC-HfC and TaC-ZrC solid solution ceramics, especially $\mathrm{Ta}_{0.8} \mathrm{Hf}_{0.2} \mathrm{C}$ and $\mathrm{Ta}_{8} \mathrm{ZrC}_{9}$ solid solution ceramics carbides, because it is known to have the highest melting temperature among $\mathrm{TaC}-\mathrm{HfC}$ and TaC-ZrC ceramics (approximately $4000^{\circ} \mathrm{C}$ and $3900{ }^{\circ} \mathrm{C}$, respectively) [16]. Barraza et al. [17] synthesized $\mathrm{TaC}-\mathrm{HfC}$ sintered ceramics by hot pressing using a mixture of micron-sized carbide powders. However, in order to acquire a fulfill ceramic, the sintering temperature must be raised to $2350^{\circ} \mathrm{C}$, which is too high and not easy to handle. Smith et al. [18] studied the unusual deformation agency of $\mathrm{Ta}_{\mathrm{x}} \mathrm{Hf}_{1-\mathrm{x}} \mathrm{C}$ ceramics. 
Unprecedented for B1 transitional metal carbides, [101](111) dislocation and slip planes were indicated, which was attributed to the difference between the stacking fault energy for $\mathrm{Ta}_{\mathrm{x}} \mathrm{Hf}_{1-\mathrm{x}} \mathrm{C}$ and the binary carbides TaC and HfC. Gladyshevsky et al. [19-21] showed that a continuous solid solution ceramic exists between the carbides TaC and ZrC. Recently, Ghaffari et al. [22] analyzed the diffusion of TaC-ZrC and TaC-HfC by SEM and XRD, and reported the presence of a single-phase ceramics in the TaC-ZrC pair.

Although some experimental studies have been performed on $\mathrm{Ta}_{1-\mathrm{x}} \mathrm{Hf}_{\mathrm{x}} \mathrm{C}$ and $\mathrm{Ta}_{1-\mathrm{x}} \mathrm{Zr}_{\mathrm{x}} \mathrm{C}$ solid solution ceramics, their theoretical research is still unclear due to experimental differences and experimental difficulties caused by high temperature stability. Considering many advantages of $\mathrm{Ta}_{1}{ }_{\mathrm{x}} \mathrm{Hf}_{\mathrm{x}} \mathrm{C}$ and $\mathrm{Ta}_{1}$ ${ }_{x} \mathrm{Zr}_{x} \mathrm{C}$ solid solution ceramics with attracted widespread attention, we systematically studied the impurity formation energy, lattice constant, volume, elastic constant, elastic modulus, Vickers hardness, fracture toughness, melting point and density of states of $\mathrm{Ta}_{1-x} \mathrm{Hf}_{x} \mathrm{C}$ and $\mathrm{Ta}_{1-x} \mathrm{Zr}_{x} \mathrm{C}$ solid solution ceramics using first-principle supercell method and virtual crystal approximation method. Further determine and compare the stability of $\mathrm{Ta}_{1-\mathrm{x}} \mathrm{Hf}_{\mathrm{x}} \mathrm{C}$ and $\mathrm{Ta}_{1-\mathrm{x}} \mathrm{Zr}_{\mathrm{x}} \mathrm{C}$ solid solution ceramics.

\section{Calculation Method And Model}

\subsection{First-principles Calculations}

In this work, $\mathrm{Ta}_{1-x} \mathrm{Hf}_{x} \mathrm{C}$ and $\mathrm{Ta}_{1-x} \mathrm{Zr}_{x} \mathrm{C}$ solid solution ceramics were calculated by the Cambridge Serial Total Energy Package (CASTEP) software using first-principle the supercell method (SC) and virtual crystal approximation method (VCA) based on the density functional theory [23-25]. The effects of exchange-correlation were considered in the framework of the generalized gradient approximation (GGA) with the Perdew-Burke-Ernzerh (PBE) [26, 27]. The norm-conservative pseudopotential was used to describe the valence electrons and the ionic core interactions [28]. In order to improve the accuracy of calculation, a plane-wave cutoff energy of $500 \mathrm{eV}$ was employed in the plane wave expansion of the wave functions, and integration of the Brillouin zone was conducted using Monkhorst-Pack $15 \times 15 \times$ $15 \mathrm{k}$-points for the supercell and virtual crystal approximation models. For modeling the $\mathrm{Hf}$ and $\mathrm{Zr}$ doped $\mathrm{TaC}$ in the whole range content $0 \leq x \leq 1$, the supercell (SC) models of $\mathrm{Ta}_{1-x} \mathrm{Hf}_{x} \mathrm{C}$ and $\mathrm{Ta}_{1-x} \mathrm{Zr}_{x} \mathrm{C}$ ceramics carbides were established in Fig. 1. For the virtual crystal approximation (VCA) method, the Ta atoms and the $\mathrm{Hf}$ or $\mathrm{Zr}$ atoms in the cubic $\mathrm{Ta}_{1-\mathrm{x}} \mathrm{Hf}_{\mathrm{x}} \mathrm{C}$ or $\mathrm{Ta}_{1-\mathrm{x}} \mathrm{Zr}_{\mathrm{x}} \mathrm{C}$ ceramics occupy the same position with an atomic mixing ratio of 1-x: $x$ [29-34].

\subsection{Formation energy Computation}

To analyze the relative stability in cubic $\mathrm{Ta}_{1-x} \mathrm{Hf}_{\mathrm{x}} \mathrm{C}$ and $\mathrm{Ta}_{1-\mathrm{x}} \mathrm{Zr}_{\mathrm{x}} \mathrm{C}$ solid solution ceramics, the formation energy $\left(E_{\text {form }}\right)$ and impurity formation energy $\left(E_{\text {imp }}\right)$ was calculated by Eq. (1-2) [35]:

$E_{\text {form }}=\left[E_{\text {tot }}\left(T_{x} R M_{y} C_{z}\right)-x E_{\text {tot }}(T a)-y E_{\text {tot }}(R M)-z E_{\text {tot }}(C)\right] /(x+y+z)(1)$

$E_{\text {imp }}=E_{\text {tot }}\left(T_{1}-{ }_{x} R M_{x} C\right)-E_{\text {tot }}(T a C)+x E_{\text {tot }}(T a)-x E_{\text {tot }}(R M)(2)$ 
where RM represents refractory metal $\mathrm{Hf}$ and $\mathrm{Zr}, \mathrm{E}_{\text {tot }}\left(\mathrm{Ta}_{1-\mathrm{x}} \mathrm{RM} \mathrm{M}_{\mathrm{x}} \mathrm{C}\right)$ is the total energy of $\mathrm{Hf}$ or $\mathrm{Zr}$ doped $\mathrm{TaC}$ systems, and $\mathrm{E}_{\text {tot }}(\mathrm{TaC})$ is the total energy of TaC. $\mathrm{E}_{\text {tot }}(\mathrm{Ta}), \mathrm{E}_{\text {tot }}(\mathrm{Hf}), \mathrm{E}_{\text {tot }}(\mathrm{Zr})$, and $\mathrm{E}_{\text {tot }}(\mathrm{C})$ are the total energy of single atom $\mathrm{Ta}, \mathrm{Hf}, \mathrm{Zr}$, and $\mathrm{C}$ in their bulk states, respectively. It is well known that the doping becomes easier as the formation energy and impurity formation energy become lower, which indicates that the stability of $\mathrm{Ta}_{1-\mathrm{x}} \mathrm{RM}_{\mathrm{x}} \mathrm{C}$ carbides is higher.

\subsection{Mechanical Computation}

For the cubic $\mathrm{Ta}_{1-\mathrm{x}} \mathrm{Hf}_{\mathrm{x}} \mathrm{C}$ and $\mathrm{Ta}_{1-\mathrm{x}} \mathrm{Zr}_{\mathrm{x}} \mathrm{C}$ solid solution ceramics, three independent elastic stiffness constants $\mathrm{C}_{11}, \mathrm{C}_{12}$, and $\mathrm{C}_{44}$ are calculated by CASTEP. The bulk modulus (B) and shear modulus $(\mathrm{G})$ of cubic $\mathrm{Ta}_{1-\mathrm{x}} \mathrm{Hf}_{\mathrm{x}} \mathrm{C}$ and $\mathrm{Ta}_{1-\mathrm{x}} \mathrm{Zr}_{\mathrm{x}} \mathrm{C}$ ceramics can be calculated by the elastic constants with the ViogtReuss-Hill (VRH) approximation from the following Eq. (3-6) [36-38]:

$$
\begin{aligned}
B & =\frac{C_{11}+2 C_{12}}{3} \\
G_{V} & =\frac{3 C_{44}+C_{11}-C_{12}}{5} \\
G_{R} & =\frac{5\left(C_{11}-C_{12}\right) C_{44}}{4 C_{44}+3\left(C_{11}-C_{12}\right)} \\
G & =\frac{G_{V}+G_{R}}{2}
\end{aligned}
$$

The Young's modulus $(E)$, Poisson's ratio $(\mathbb{\nabla})$, Vickers hardness $\left(H_{V}\right)$, and fracture toughness $\left(K_{I C}\right)$ are computed by bulk modulus (B) and shear modulus (G) with Eq. (7-10) [39-46]:

$$
\begin{gathered}
E=\frac{9 G B}{3 B+G} \\
v=\frac{3 B-2 G}{2(3 B+G)} \\
H_{\mathrm{v}}=0.92 k^{1.137} G^{0.708} \\
K_{I C}=V_{0}^{1 / 6} G(B / G)^{1 / 2}
\end{gathered}
$$

Where $V_{0}$ is the volume per atom; $k$ is the $G / B$ ratio.

The critical energy release rate $\left(G_{I C}\right)$ is calculated using Young's modulus $(E)$, Poisson's ratio $(\mathbb{Z})$ and fracture toughness $\left(\mathrm{K}_{\mathrm{IC}}\right)$ with Eq. (11) [47]:

$$
G_{I C}=K_{I C}^{2}\left(\frac{1-v^{2}}{E}\right)
$$

\section{Results And Discussion}




\subsection{Structural stability}

Figure 2 shows the formation energy $\left(E_{\text {form }}\right)$ and impurity formation energy $\left(E_{\text {imp }}\right)$ of $\mathrm{Ta}_{1-x} \mathrm{Hf}_{x} \mathrm{C}$ and $\mathrm{Ta}_{1-}$ ${ }_{x} \mathrm{Zr}{ }_{x} \mathrm{C}$ solid solution ceramics as a function of $\mathrm{Hf}$ or $\mathrm{Zr}$ content $x$. The formation energy $\left(E_{\text {form }}\right)$ and impurity formation energy $\left(E_{\text {imp }}\right)$ of $\mathrm{Ta}_{1-x} \mathrm{Hf}_{x} \mathrm{C}$ and $\mathrm{Ta}_{1-x} \mathrm{Zr}_{x} \mathrm{C}$ are always negative with the increase of $\mathrm{Hf}$ and $\mathrm{Zr}$ content $x$, which indicates that the formation of solid solution ceramics is advantageous from energetics. Moreover, with the increase of $\mathrm{Hf}$ and $\mathrm{Zr}$ content $x$, the formation energy $\left(E_{\text {form }}\right)$ and impurity formation energy $\left(E_{\text {imp }}\right)$ of $\mathrm{Ta}_{1-x} \mathrm{Hf}_{x} \mathrm{C}$ and $\mathrm{Ta}_{1-x} \mathrm{Zr}_{x} \mathrm{C}$ solid solution ceramics become lower, thus the structural stability is better. In other words, doping $\mathrm{Hf}$ and $\mathrm{Zr}$ helps to enhance the stability of $\mathrm{Ta}_{1-x} \mathrm{Hf}_{x} \mathrm{C}$ and $\mathrm{Ta}_{1-x} Z \mathrm{r}_{x} \mathrm{C}$. Furthermore, when the $\mathrm{Hf}$ and $\mathrm{Zr}$ doped content are the same, the formation energy $\left(E_{\text {form }}\right)$ and impurity formation energy $\left(E_{\text {imp }}\right)$ of $\mathrm{Ta}_{1-x} \mathrm{Zr}_{x} \mathrm{C}$ are lower, which indicates that $\mathrm{Zr}$ doped $\mathrm{TaC}$ is more advantageous than $\mathrm{Hf}$ doped TaC for system stability. Therefore, $\mathrm{Ta}_{1-x} \mathrm{Zr}_{x} \mathrm{C}$ solid solution ceramics is more stable.

Figure 3 shows the lattice constants (a) and volume $(\mathrm{V})$ of $\mathrm{Ta}_{1-x} \mathrm{Hf}_{x} \mathrm{C}$ and $\mathrm{Ta}_{1-x} \mathrm{Zr}_{x} \mathrm{C}$ solid solution ceramics as a function of $\mathrm{Hf}$ or $\mathrm{Zr}$ content $x$ by supercell (SC) method and virtual crystal approximation (VCA) method. From Fig. 3, the calculated geometric results of these two methods are nearly the same, which are also consistent with the available experimental data and theoretical results in the Ref.[48,49]. As a result, these also verify their mutual consistency and correctness. With the increase of $\mathrm{Hf}$ or $\mathrm{Zr}$ content, the lattice constant and volume of $\mathrm{Ta}_{1-x} \mathrm{Hf}_{x} \mathrm{C}$ and $\mathrm{Ta}_{1-x} \mathrm{Zr}_{x} \mathrm{C}$ solid solution ceramics increase, which are mainly attributed to the larger atomic radii of $\mathrm{Hf}(1.58 \AA)$ and $\operatorname{Zr}(1.55 \AA)$ than $\operatorname{Ta}(1.45 \AA)$. In addition, the change of the lattice constant of $\mathrm{Ta}_{1-x} \mathrm{Hf}_{x} \mathrm{C}$ and $\mathrm{Ta}_{1-x} \mathrm{Zr}_{x} \mathrm{C}$ solid solution ceramics with the doping content is also in agreement with the experiment [50,51].

\subsection{Mechanical properties}

Figure 4 (a) shows the elastic constants of $\mathrm{Ta}_{1-x} \mathrm{Hf}_{x} \mathrm{C}$ and $\mathrm{Ta}_{1-x} \mathrm{Zr}_{x} \mathrm{C}$ solid solution ceramics. For cubic crystals, the criteria of the mechanical stability are $\mathrm{C}_{11}>0, \mathrm{C}_{44}>0, \mathrm{C}_{11}-\mathrm{C}_{12}>0$ and $\mathrm{C}_{11}+2 \mathrm{C}_{12}>0$ [52]. Obviously, the calculated elastic constants of $\mathrm{Ta}_{1-x} \mathrm{Hf}_{\mathrm{x}} \mathrm{C}$ and $\mathrm{Ta}_{1-\mathrm{x}} \mathrm{Zr}_{\mathrm{x}} \mathrm{C}$ ceramics meet the above criteria, suggesting that they are mechanically stable. For the terminated monocarbides in $\mathrm{Ta}_{1-}{ }_{x} \mathrm{Hf}_{\mathrm{x}} \mathrm{C}$ and $\mathrm{Ta}_{1-}$ ${ }_{x} \mathrm{Zr}_{\mathrm{x}} \mathrm{C}$ systems (i.e. TaC, $\mathrm{HfC}, \mathrm{ZrC}$ ), their calculated elastic constants $\left(\mathrm{C}_{\mathrm{ij}}\right)$ are very consistent with the experimental data and theoretical values in the Ref. [53-55]. With the increase of the $\mathrm{Hf}$ and $\mathrm{Zr}$ content in Fig. 4(a), the elastic constants $\mathrm{C}_{11}$ of the $\mathrm{Ta}_{1-\mathrm{x}} \mathrm{Hf}_{\mathrm{x}} \mathrm{C}$ and $\mathrm{Ta}_{1-\mathrm{x}} \mathrm{Zr}_{\mathrm{x}} \mathrm{C}$ solid solution ceramics firstly increase, and subsequently almost decrease. In particular, the $\mathrm{C}_{11}$ of $\mathrm{Ta}_{1-\mathrm{x}} \mathrm{Hf}_{\mathrm{x}} \mathrm{C}$ solid solution has a peak (maximum) with the doping content of $\mathrm{x}=0.2$, which means that $\mathrm{Ta}_{0.8} \mathrm{Hf}_{0.2} \mathrm{C}$ has the highest compressive strength along the $x$ and $z$ axes under uniaxial stress. While the elastic constants $\mathrm{C}_{12}$ and $\mathrm{C}_{44}$ fluctuate around $160 \mathrm{GPa}$, with the increase of doping content. In addition, when the $\mathrm{Hf}$ and $\mathrm{Zr}$ doping contents are the same, the $\mathrm{C}_{12}$ and $\mathrm{C}_{44}$ of $\mathrm{Ta}_{1-\mathrm{x}} \mathrm{Hf}_{\mathrm{x}} \mathrm{C}$ are larger than $\mathrm{Ta}_{1-\mathrm{x}} \mathrm{Zr}_{\mathrm{x}} \mathrm{C}$, which indicates that the doping $\mathrm{Hf}$ under uniaxial stress has greater compressive strength and shear strength along the $x$ and $z$ axes. 
Melting point $\left(T_{m}\right)$ is one of the important data for developing UHTC ceramics. The melting point of $\mathrm{Ta}_{1-}$ ${ }_{x} \mathrm{Hf}_{\mathrm{x}} \mathrm{C}$ and $\mathrm{Ta}_{1}-\mathrm{zr}_{\mathrm{x}} \mathrm{C}$ solid solution ceramics is estimated by Eq. (12) based on the elastic constant $\mathrm{C}_{11}$ $[56,57]$ :

$$
T_{\mathrm{m}}=553 \mathrm{~K}+\left(\frac{5.91 \mathrm{~K}}{\mathrm{GPa}}\right) C_{11}
$$

Where the $\mathrm{C}_{11}$ is in units of $\mathrm{GPa}$ and the standard error is about $\pm 300 \mathrm{~K}$.

Figure 4 (b) shows the melting points of $\mathrm{Ta}_{1-x} \mathrm{Hf}_{\mathrm{x}} \mathrm{C}$ and $\mathrm{Ta}_{1-\mathrm{x}} \mathrm{Zr}_{\mathrm{x}} \mathrm{C}$ solid solution ceramics. From Fig. 4 (b), our calculated melting points $\left(\mathrm{T}_{\mathrm{m}}\right)$ of terminal monocarbides in $\mathrm{Ta}_{1-} \mathrm{Hf}_{\mathrm{x}} \mathrm{C}$ and $\mathrm{Ta}_{1-\mathrm{x}} \mathrm{Zr}_{\mathrm{x}} \mathrm{C}$ systems are consistent with the available experimental values in Refs. [58, 59]. As shown in Eq. (12), the melting point $\left(T_{m}\right)$ is proportional to the elastic constant $C_{11}$, that is, the $T_{0.8} \mathrm{Hf}_{0.2} \mathrm{C}$ and $\mathrm{Ta}_{0.89} \mathrm{Zr}_{0.11} \mathrm{C}$ ceramics have the highest melting points, which are in agreement with the experimental observation [16].

Pugh [60] predicts the brittleness and ductility of materials according to the value of $B / G$, that is, when $\mathrm{B} / \mathrm{G}$ is smaller than 1.75 , the materials is brittle; otherwise the materials is ductile. Obviously, it can be found that the $\mathrm{Ta}_{1-x} \mathrm{Hf}_{\mathrm{x}} \mathrm{C}$ and $\mathrm{Ta}_{1-x} \mathrm{Zr}_{\mathrm{x}} \mathrm{C}$ solid solutions are brittle materials in Fig. 5 (a), and our calculated $\mathrm{B} / \mathrm{G}$ of terminal monocarbides in $\mathrm{Ta}_{1-\mathrm{x}} \mathrm{Hf}_{\mathrm{x}} \mathrm{C}$ and $\mathrm{Ta}_{1-\mathrm{x}} \mathrm{Zr}_{\mathrm{x}} \mathrm{C}$ systems are consistent with the previous theoretical DFT report [61] and experimental values [62]. Moreover, the $B / G$ of $\mathrm{Ta}_{1-x} \mathrm{Hf}_{\mathrm{x}} \mathrm{C}$ ceramics is lower than that of $\mathrm{Ta}_{1-} \mathrm{Hf}_{\mathrm{x}} \mathrm{C}$ at the same doping content of $\mathrm{Hf}$ and $\mathrm{Zr}$, suggesting that $\mathrm{Ta}_{1-}$ ${ }_{x} \mathrm{Hf}_{\mathrm{x}} \mathrm{C}$ is more brittle. In addition, the Poisson's ratio $(\mathbb{\nabla})$ can also be a criterion for ductility and brittleness [63]. Similar to $B / G$, when $\otimes$ is less than 0.26 , the materials become brittle; otherwise the materials show

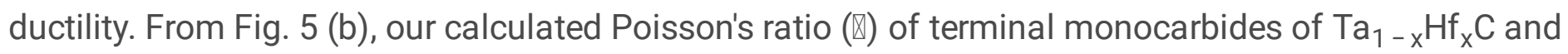
$\mathrm{Ta}_{1-\mathrm{x}} \mathrm{Zr}_{\mathrm{x}} \mathrm{C}$ solid solutions are in agreement with the experimental values [64] and the theoretical DFT calculations [61]. Obviously, the $\mathrm{Ta}_{1-x} \mathrm{Hf}_{x} \mathrm{C}$ and $\mathrm{Ta}_{1-x} \mathrm{Zr}_{x} \mathrm{C}$ solid solution ceramics are also brittle materials, which is consistent with the above $\mathrm{B} / \mathrm{G}$ analysis.

From Fig. 5(c-e), our calculated Young's modulus (E), bulk modulus (B) and shear modulus (G) of terminal monocarbides in $\mathrm{Ta}_{1-x} \mathrm{Hf}_{\mathrm{x}} \mathrm{C}$ and $\mathrm{Ta}_{1-x} \mathrm{Zr}_{x} \mathrm{C}$ systems are consistent with the experimental data and previous theoretical DFT results $[62,65,66]$. The Young's modulus $(E)$ mainly reflects the compression resistance of materials. From Fig. 5 (c), the Young's modulus (E) of $\mathrm{Ta}_{1-x} \mathrm{Hf}_{\mathrm{x}} \mathrm{C}$ and $\mathrm{Ta}_{1-\mathrm{x}} \mathrm{Zr}_{\mathrm{x}} \mathrm{C}$ solid solution ceramics has a peak (maximum). Furthermore, $\mathrm{Ta}_{0.8} \mathrm{Hf}_{0.2} \mathrm{C}$ has the largest compression resistance. From Fig. 5 (d), with the increase of the $\mathrm{Hf}$ or $\mathrm{Zr}$ content, the bulk modulus (B) of $\mathrm{Ta}_{1-x} \mathrm{Hf}_{\mathrm{x}} \mathrm{C}$ and $\mathrm{Ta}_{1-x} \mathrm{Zr}_{x} \mathrm{C}$ solid solution ceramics become smaller. The shear modulus $(\mathrm{G})$ can survey the shear deformation resistance of materials. From Fig. 5 (e), the shear modulus $(G)$ of $\mathrm{Ta}_{1-x} \mathrm{Hf}_{\mathrm{x}} \mathrm{C}$ and $\mathrm{Ta}_{1-\mathrm{x}} \mathrm{Zr}_{\mathrm{x}} \mathrm{C}$ solid solution ceramics have the peak. In particular, $\mathrm{Ta}_{0.8} \mathrm{Hf}_{0.2} \mathrm{C}$ has the largest shear modulus $(\mathrm{G})$, so it has the strongest shear resistance.

Figure 5 (f) shows the Vickers hardness $\left(\mathrm{H}_{\mathrm{V}}\right)$ of $\mathrm{Ta}_{1-\mathrm{x}} \mathrm{Hf}_{\mathrm{x}} \mathrm{C}$ and $\mathrm{Ta}_{1-\mathrm{x}} \mathrm{Zr}_{\mathrm{x}} \mathrm{C}$ solid solution ceramics as a function of $\mathrm{Hf}$ or $\mathrm{Zr}$ content. The calculated Vickers Hardness $\left(\mathrm{H}_{\mathrm{V}}\right)$ of terminal monocarbides in $\mathrm{Ta}_{1}$ - 
${ }_{x} \mathrm{Hf}_{\mathrm{x}} \mathrm{C}$ and $\mathrm{Ta}_{1-\mathrm{x}} \mathrm{Zr}_{\mathrm{x}} \mathrm{C}$ systems are consistent with experimental and other DFT calculated results [18, 40, 67]. Furthermore, the Vickers Hardness $\left(\mathrm{H}_{\mathrm{V}}\right)$ of $\mathrm{Ta}_{1-\mathrm{x}} \mathrm{Hf}_{\mathrm{x}} \mathrm{C}$ solid solution ceramics exhibited crest and trough shape with increasing $\mathrm{Hf}$ content, which is consistent with the available experimental Vickers hardness $\left(\mathrm{H}_{\mathrm{V}}\right)[68,69]$. In particular, it can be found that $\mathrm{Ta}_{0.8} \mathrm{Hf}_{0.2} \mathrm{C}$ has the highest Vickers hardness $\left(H_{V}\right)$.

In fact, fracture toughness $\left(\mathrm{K}_{\mathrm{IC}}\right)$ plays a major role on the design of ultrahigh temperature ceramic materials, which is used to describe the resistance of a material against crack propagation [42-46]. From Fig. 5 (g), our calculated fracture toughness $\left(\mathrm{K}_{\mathrm{IC}}\right)$ of terminal monocarbides in $\mathrm{Ta}_{1-\mathrm{x}} \mathrm{Hf}_{\mathrm{x}} \mathrm{C}$ and $\mathrm{Ta}_{1-\mathrm{x}} \mathrm{Zr}_{\mathrm{x}} \mathrm{C}$ systems are consistent with the available experimental data $[67,70,71]$. Furthermore, $\mathrm{Ta}_{0.8} \mathrm{Hf}_{0.2} \mathrm{C}$ has the largest fracture toughness. In addition, a small amount of $\mathrm{Hf}$ or $\mathrm{Zr}$ doping will increase the fracture toughness $\left(\mathrm{K}_{\mathrm{IC}}\right)$ of $\mathrm{Ta}_{1-\mathrm{x}} \mathrm{Hf}_{\mathrm{x}} \mathrm{C}$ and $\mathrm{Ta}_{1-\mathrm{x}} \mathrm{Zr}_{\mathrm{x}} \mathrm{C}$ ceramics, while the fracture toughness $\left(\mathrm{K}_{\mathrm{IC}}\right)$ of the $\mathrm{Ta}_{1-}$ ${ }_{x} \mathrm{Hf}_{\mathrm{x}} \mathrm{C}$ and $\mathrm{Ta}_{1-\mathrm{x}} \mathrm{Zr}_{\mathrm{x}} \mathrm{C}$ ceramics will decrease significantly when the content of $\mathrm{Hf}$ and $\mathrm{Zr}$ is excessive. Similar to $K_{I C}$, the critical energy release rate $\left(G_{I C}\right)$ is used to estimate the energy required to propagate cracks in the material [42]. From Fig. $5(\mathrm{~h})$, the critical energy release rate $\left(\mathrm{G}_{\mathrm{IC}}\right)$ of $\mathrm{Ta}_{1-\mathrm{x}} \mathrm{Hf}_{\mathrm{x}} \mathrm{C}$ and $\mathrm{Ta}_{1-}$ ${ }_{x} \mathrm{Zr}_{\mathrm{x}} \mathrm{C}$ ceramics have the maximum value with $\mathrm{x}=0.1$, which shows the similar tendency of fracture toughness.

\subsection{Electronic properties}

To obtain the intrinsic properties of electronic structures of $\mathrm{Hf}$ and $\mathrm{Zr}$ doped $\mathrm{TaC}$, we calculated the total electronic density of states (DOS) for pure and four content of $\mathrm{Hf}$ and $\mathrm{Zr}$ doped TaC systems. Figure 6 shows the density of states (DOS) of $\mathrm{Ta}_{1-x} \mathrm{Hf}_{x} \mathrm{C}$ and $\mathrm{Ta}_{1-x} \mathrm{Zr}_{x} \mathrm{C}$ solid solution ceramics, which is consistent with the available experimental $\mathrm{X}$-ray spectrums [72].

From Fig. 6, the density of state the $\mathrm{Ta}_{1-x} \mathrm{Hf}_{x} \mathrm{C}$ and $\mathrm{Ta}_{1-x} \mathrm{Zr}_{x} \mathrm{C}$ solid solution ceramics have two peaks below the Fermi level $\left(\mathrm{E}_{\mathrm{F}}\right)$. In the whole view from Fig. 6 , the secondary peak at deepest energy level becomes higher with increasing of $\mathrm{Hf}$ or $\mathrm{Zr}$ content. Furthermore, the main peak of the DOS of $\mathrm{Ta}_{0.75} \mathrm{Hf}_{0.25} \mathrm{C}$ at about $-4 \mathrm{eV}$ becomes wider than that of TaC. Therefore, the hybridization between the system atoms becomes stronger, so the $\mathrm{Ta}_{0.75} \mathrm{Hf}_{0.25} \mathrm{C}$ is more stable than $\mathrm{TaC}$. With the increase the content of $\mathrm{Hf}$, the main peak of density of states at about $-4 \mathrm{eV}$ for $\mathrm{Ta}_{1-\mathrm{x}} \mathrm{Hf}_{\mathrm{x}} \mathrm{C}$ system becomes wider, which suggests that the $\mathrm{Ta}_{1-x} \mathrm{Hf}_{x} \mathrm{C}$ ceramics become more and more stable. Similarly, in Fig. 6 (b), the main peak of density of states at about $-4 \mathrm{eV}$ for $\mathrm{Ta}_{1-\mathrm{x}} \mathrm{Zr}_{\mathrm{x}} \mathrm{C}$ becomes wider with increasing the content of $\mathrm{Hf}$, which indicates that $\mathrm{Ta}_{1-\mathrm{x}} \mathrm{Zr}_{\mathrm{x}} \mathrm{C}$ ceramics become more stable. In a world, the stability of $\mathrm{Ta}_{1-\mathrm{x}} \mathrm{Hf}_{\mathrm{x}} \mathrm{C}$ and $\mathrm{Ta}_{1-\mathrm{x}} \mathrm{Zr} \mathrm{r}_{\mathrm{x}} \mathrm{C}$ increases with the increase of $\mathrm{Hf}$ and $\mathrm{Zr}$ content, which are consistent with the above results of formation energy.

\section{Conclusion}


In conclusion, we have systematically investigated the impurity formation energy, lattice constant, volume, elastic constants, elastic moduli, melting points, fracture toughness and density of states of $\mathrm{Hf}$ and $\mathrm{Zr}$ doped TaC systems by first-principles supercell (SC) and virtual crystal approximation (VCA) methods. The results show that the formation energy and impurity formation energy of $\mathrm{Ta}_{1-x} \mathrm{Hf}_{\mathrm{x}} \mathrm{C}$ and $\mathrm{Ta}_{1-\mathrm{x}} \mathrm{Zr}_{\mathrm{x}} \mathrm{C}$ ceramics decrease with the increasing content of $\mathrm{Hf}$ and $\mathrm{Zr}$, which indicates that $\mathrm{Ta}_{1-\mathrm{x}} \mathrm{Hf}_{\mathrm{x}} \mathrm{C}$ and $\mathrm{Ta}_{1-x} \mathrm{Zr}_{\mathrm{x}} \mathrm{C}$ ceramics becomes more stable as increasing the content of $\mathrm{Hf}$ and $\mathrm{Zr}$. The lattice constant and volume become larger as increasing the content of $\mathrm{Hf}$ and $\mathrm{Zr}$, since the atomic radius of $\mathrm{Hf}$ and $\mathrm{Zr}$ are larger than that of $\mathrm{Ta}$. In addition, the results also show that the impurity formation energy of $\mathrm{Ta}_{1-\mathrm{x}} \mathrm{Zr}_{\mathrm{x}} \mathrm{C}$ ceramics is lower than that of $\mathrm{Ta}_{1-\mathrm{x}} \mathrm{Hf}_{\mathrm{x}} \mathrm{C}$ when the contents of $\mathrm{Hf}$ and $\mathrm{Zr}$ are the same. As a result, $\mathrm{Ta}_{1-\mathrm{x}} \mathrm{Zr}_{\mathrm{x}} \mathrm{C}$ ceramic is more stable. The results of mechanical properties indicate that $\mathrm{Ta}_{1-\mathrm{x}} \mathrm{Hf}_{\mathrm{x}} \mathrm{C}$ and $\mathrm{Ta}_{1-\mathrm{x}} \mathrm{Zr}_{\mathrm{x}} \mathrm{C}$ ceramics carbides are mechanically stable and brittle. The bulk modulus of $\mathrm{Ta}_{1-\mathrm{x}} \mathrm{Hf}_{\mathrm{x}} \mathrm{C}$ and $\mathrm{Ta}_{1-\mathrm{x}} \mathrm{Zr}_{\mathrm{x}} \mathrm{C}$ ceramics decreases with increasing content of $\mathrm{Hf}$ and $\mathrm{Zr}$. In particular, $\mathrm{Ta}_{0.8} \mathrm{Hf}_{0.2} \mathrm{C}$ has the highest hardness, largest fracture toughness and highest melting temperature. $\mathrm{And}^{\mathrm{T}} \mathrm{a}_{0.8} \mathrm{Hf}_{0.2} \mathrm{C}$ also exists the strongest compression resistance and shear resistance. Finally, we hope that our calculations will provide useful guidance for the development of ultra-high temperature ceramics of $\mathrm{Ta}_{1-{ }_{x}} \mathrm{Hf}_{\mathrm{x}} \mathrm{C}$ and $\mathrm{Ta}_{1-\mathrm{x}} \mathrm{Zr}_{\mathrm{x}} \mathrm{C}$ carbides.

\section{Declarations}

\section{Acknowledgements}

This work was supported by the National Natural Science Foundation of China (Grant Nos. 11104203, 11075116, 50972014, 51072024 and 51132002) and the Foundation of introduction of talent of Tianjin Normal University (Grant No. 5RL100)

\section{References}

[1] Schonfeld K, Martin HP, Michaelis A. Pressureless sintering of ZrC with variable stoichiometry. J Adv Ceram 2017, 6: 165-175.

[2] Kurbatkina VV, Patsrea El, Vorotilo SA, et al. Conditions for fabricating single-phase (Ta,Zr)C carbide by SHS from mechanically activated reaction mixtures. Ceram Int 2016, 42: 16491-16498.

[3] Liu JX, Huang X, Zhang GJ. Pressureless sintering of hafnium carbide-silicon carbide ceramics. J Am Ceram Soc 2013, 96: 1751-1756.

[4] Patsrea El, Levashov EA, Kurbatkina VV, et al. Production of ultra-high temperature carbide ( $\mathrm{Ta}, \mathrm{Zr}) \mathrm{C}$ by self-propagating high-temperature synthesis of mechanically activated mixtures. Ceram Int 2015, 41: 8885-8893. 
[5] Ghaffari SA, Faghihi-Sani MA, Golestani-Fard F, et al. Spark plasma sintering of TaC-HfC UHTC via disilicides sintering aids. J Eur Ceram Soc 2013, 33 1479-1484.

[6] Yu ZJ, Lv X, Lai SY, et al. ZrC-ZrB ${ }_{2}$-SiC ceramic nanocomposites derived from a novel single-source precursor with high ceramic yield. J Adv Ceram 2019, 8: 112-120.

[7] Hao W, Ni N, Guo FW, et al. High fracture toughness of HfC through nano-scale templating and novel sintering aids. J Am Ceram Soc 2019, 102: 997-1009.

[8] Oyama ST. The Chemistry of Transition Metal Carbides and Nitrides. Glasgow: Blackie Academic and Professional, 1996, pp.1-27.

[9] Pierson HO. Handbook of Refractory Carbides and Nitrides. Massachusetts, USA: Noyes Publications Westwood, 1996, pp.5-16.

[10] Jiang D, Wang Q, Hu W, et al. The effect of tantalum (Ta) doping on mechanical properties of tungsten (W): A first-principles study. J Mater Res 2016, 31 3401-3408.

[11] Sciti D, Silvestroni L, Guicciardi S, et al. Processing, mechanical properties and oxidation behavior of $\mathrm{TaC}$ and $\mathrm{HfC}$ composites containing 15 vol\% $\mathrm{TaSi}_{2}$ or $\mathrm{MoSi}_{2}$. J Mater Res 2009, 24: 2056-2065.

[12] Zhang X, Hilmas GE, Fahrenholtz WG, et al. Hot pressing of tantalum carbide with and without sintering additives. J Am Ceram Soc 2007, 90: 393-401.

[13] Huang S, Vanmeensel K, Vander Biest O, et al. Binderless WC and WC-VC materials obtained by pulsed electric current sintering. Int J Refract Met Hard Mater 2008, 26: 41-47.

[14] Wang XG, Liu JX, Kan YM, et al. Effect of ceramics formation on densification of hot-pressed ZrC ceramics with MC ( $M=V, N b$, and Ta) additions. J Eur Ceram Soc 2012, 32: 1795-1802.

[15] Simonenko EP, Ignatov NA, Simonenko NP, et al. Synthesis of highly dispersed super-refractory tantalum-zirconium carbide $\mathrm{Ta}_{4} \mathrm{ZrC}_{5}$ and tantalum-hafnium carbide $\mathrm{Ta}_{4} \mathrm{HfC}_{5}$ via sol-gel technology. Russ J Inorg Chem 2011, 56: 1681-1687.

[16] Andrievskii RA, Strel'nikova NS, Poltoratskii NI, et al. Melting point in systems ZrC-HfC, TaC-ZrC, TaCHfC. Powder Metall Met C 1967, 6: 65-67.

[17] Barraza OC, Grasso S, Nasiri NA, et al. Sintering behaviour, ceramics formation and characterisation of TaC, HfC and TaC-HfC fabricated by spark plasma sintering. J Eur Ceram Soc 2016, 36: 1539-1548.

[18] Smith CJ, Yu X, Guo Q, et al. Phase, hardness, and deformation slip behavior in mixed $\mathrm{Hf}_{X} \mathrm{Ta}_{1-x} \mathrm{C}$. Acta Mater 2018, 145: 142-153. 
[19] Gladyshevsky El, Fedorov TF, Gorshkova LV. The zirconium-tantalum-carbon system. Russ J Inorg Chem 1964, 9: 639-642.

[20] Avgustinik Al, Ordan'yan SS. Structure of alloys of Zr-C-Ta system. Zh Prikl Kim 1966, 39: 318-323.

[21] Rudy E. Ternary phase equilibria in transition metal-boron-carbon-silicon systems. Techn Rep AFMLTR 1969, 65: 334-360.

[22] Ghaffari SA, Faghihi Sani MA, Fard FG, et al. Diffusion and ceramics formation between the binary carbides of TaC, HfC and ZrC. Int J Refract Met Hard Mater 2013, 41: 180-184.

[23] Segall MD, Lindan PLD, Probert MJ, et al. First-principles simulation: ideas, illustrations and the CASTEP code. J Phys Condens Matter 2002, 14: 2717-2724.

[24] Zhang $\mathrm{H}$, Wang $\mathrm{XH}$, Ma YH, et al. Crystal structure determination of nanolaminated $\mathrm{Ti}_{5} \mathrm{Al}_{2} \mathrm{C}_{3}$ by combined techniques of XRPD, TEM and ab initio calculations. J Adv Ceram 2012, 1: 268-273.

[25] Li JP, Meng SH, Niu JH, et al. Electronic structures and optical properties of monoclinic $\mathrm{ZrO}_{2}$ studied by first-principles local density approximation + Uapproach. J Adv Ceram 2017, 6: 43-49.

[26] Li X, Chen X, Han L, et al. First-principles study of the structural, elastic and electronic properties of $\mathrm{Pt}_{3} \mathrm{M}$ alloys. J Mater Res 2016, 31: 2956-2963.

[27] Sun S, Fu H, Lin J, et al. The stability, mechanical properties, electronic structures and thermodynamic properties of $(\mathrm{Ti}, \mathrm{Nb}) \mathrm{C}$ compounds by first-principles calculations. J Mater Res 2018, 33: 495-506.

[28] Hamann DR. Generalized norm-conserving pseudopotentials. Phys Rev B 1989, 40: 2980.

[29] Liu SY, Liu S, Li DJ, et al. Structure, phase transition, and electronic properties of $\mathrm{K}_{1-x} \mathrm{Na}_{x} \mathrm{NbO}_{3}$ solid solutions from first-principles theory. J Am Ceram Soc 2014, 97: 4019-4023.

[30] Liu SY, Zhang E, Liu S, et al. Composition- and pressure-induced relaxor ferroelectrics: First-principles calculations and landau-devonshire theory. J Am Ceram Soc 2016, 99: 3336-3342.

[31] Liu SY, Meng Y, Liu S, et al. Phase stability, electronic structures, and superconductivity properties of the $\mathrm{BaPb}_{1-x} \mathrm{Bi}_{x} \mathrm{O}_{3}$ and $\mathrm{Ba}_{1-x} \mathrm{~K}_{x} \mathrm{BiO}_{3}$ perovskites. J Am Ceram Soc 2017, 100: 1221-1230.

[32] Liu SY, Meng Y, Liu S, et al. Compositional phase diagram and microscopic mechanism of $\mathrm{Ba}_{1-x} \mathrm{Ca}_{x} \mathrm{Zr}_{y} \mathrm{Ti}_{1-y} \mathrm{O}_{3}$ relaxor ferroelectrics. Phys Chem Chem Phys 2017, 19: 22190-22196.

[33] Liu SY, Chen QY, Liu S, et al. Electronic structures and transition temperatures of high-T ${ }_{c}$ cuprate superconductors from first-principles calculations and Landau theory. J Alloys Compd 2018, 764: 869880 . 
[34] Liu SY, Shao QS, Yu DS, et al. First-principles study on the geometric and electronic structures and phase transition of $\mathrm{PbZr}_{1-x} \mathrm{Ti}_{x} \mathrm{O}_{3}$ solid solutions. Chin Phys B 2013, 22: 017702.

[35] Liu SY, Shang JX, Wang FH, et al. Surface segregation of Si and its effect on oxygen adsorption on a Y-TiAl(111) surface from first principles. J Phys Condens Matter 2009, 21: 225005.

[36] Voigt W. Lehrbuch der Kristallophysic. Leipzig, Teubner Verlag, 1928.

[37] Reuss A. Berechung der Fliessgrenze von Mischkristalle auf Ground der Plastizitatsbedigung fur Einkristalle. Z Angew Math Mech 1929, 9: 49-58.

[38] Hill R. The elastic behaviour of a crystalline aggregate. Proc Phys Soc Lond A 1952, 65: 349-354.

[39] Yang J, Gao FM. First principles calculations of mechanical properties of cubic $5 d$ transition metal monocarbides. Physica B: Condensed Matter 2012, 407: 3527-3534.

[40] Tian YJ, Xu B, Zhao ZH. Microscopic theory of hardness and design of novel superhard crystals. Int J Refract Met Hard Mater 2012, 33: 93-106.

[41] Niu HY, Niu SW, Oganov AR. Simple and accurate model of fracture toughness of solids. J Appl Phys 2019, 125: 065105.

[42] Gong JH, Wang JQ, Guan ZD. Indentation toughness of ceramics: A modified approach. J Mater Sci 2002, 37: 865-869.

[43] Gong JH. Determining indentation toughness by incorporating true hardness into fracture mechanics equations. J Eur Ceram Soc 1999, 19: 1585-1592.

[44] Gong JH, Peng ZJ, Miao HZ. Analysis of the nanoindentation load-displacement curves measured on high-purity fine-grained alumina. J Eur Ceram Soc 2005, 25: 649-654.

[45] Gong JH. Indentation toughness of ceramics: a statistical analysis. Ceram Int 2002, 28: 767-772.

[46] Gong JH, Miao HZ, Peng ZJ. Analysis of the nanoindentation data measured with a berkovich indenter for brittle materials: effect of the residual contact stress. Acta Mater 2004, 52: 785-793.

[47] Gong JH. Fracture mechanics of ceramics. Beijing, CN: Tsinghua UniversityPress, 2001, pp.94-101.

[48] Yan XL, Constantin L, Lu YF, et al. $\left(\mathrm{Hf}_{0.2} \mathrm{Zr}_{0.2} \mathrm{Ta}_{0.2} \mathrm{Nb}_{0.2} \mathrm{Ti}_{0.2}\right) \mathrm{C}$ high-entropy ceramics with low thermal conductivity. J Am Ceram Soc 2018, 101: 4486-4491.

[49] Ye BL, Wen TQ, Huang KH, et al. First-principles study, fabrication, and characterization of $\left(\mathrm{Hf}_{0.2} \mathrm{Zr}_{0.2} \mathrm{Ta}_{0.2} \mathrm{Nb}_{0.2} \mathrm{Ti}_{0.2}\right) \mathrm{C}$ high-entropy ceramic. J Am Ceram Soc 2019, 102: 4344-4352. 
[50] Ha DG, Kim J, Han JS, et al. Synthesis and properties of $\left(\mathrm{Hf}_{1-x} \mathrm{Ta}_{\chi}\right) \mathrm{C}$ ceramics carbides. Ceram Int 2018, 44: 19247-19253.

[51] Vorotilo S, Sidnov K, Mosyagin IY, et al. Ab-initio modeling and experimental investigation of properties of ultra-high temperature solid solutions $\mathrm{Ta}_{x} \mathrm{Zr}_{1-x} \mathrm{C}$. J Alloys Compd 2019, 778: 480-486.

[52] Huang B, Duan YH, Sun Y, et al. Electronic structures, mechanical and thermodynamic properties of cubic alkaline-earth hexaborides from first principles calculations. J Alloys Compd 2015, 635: 213-224.

[53] Weber W. Lattice dynamics of transition-metal carbides. Phys Rev B 1973, 8: 5082-5092.

[54] Li H, Zhang LT, Zeng QF, et al. Structural, elastic and electronic properties of transition metal carbides TMC (TM=Ti, Zr, Hf and Ta) from first-principles calculations. Solid State Commun 2011, 151: 602-606.

[55] Gautam GS, Hari Kumar KC. Elastic, thermochemical and thermophysical properties of rock salt-type transition metal carbides and nitrides: A first principles study. J Alloys Compd 2014, 587: 380-386.

[56] Fine ME, Brown LD, Marcus HL. Elastic constants versus melting temperature in metals. Scr Metall 1984, 18: 951-956.

[57] Gu JB, Wang CJ, Zhang WX, et al. High-pressure structure and elastic properties of tantalum single crystal: First principles investigation. Chin Phys B 2016, 25: 126103.

[58] Fahrenholtz WG, Hilmas GE, Talmy IG, et al. Refractory diborides of zirconium and hafnium. J Am Ceram Soc 2007, 90: 1347-1364.

[59] lonescu E, Bernard S, Lucas R, et al. Polymer-derived ultra-high temperature ceramics (UHTCs) and related materials. Adv Eng Mater 2019, 21:1900269.

[60] Pugh SF. Relations between the elastic moduli and the plastic properties of polycrystalline pure metals. Phil Mag Ser 1954, 45: 823-843.

[61] Liu YZ, Jiang YH, Zhou R, et al. First principles study the stability and mechanical properties of MC $(\mathrm{M}=\mathrm{Ti}, \mathrm{V}, \mathrm{Zr}, \mathrm{Nb}, \mathrm{Hf}$ and Ta) compounds. J Alloys Compd 2014, 582: 500-504.

[62] Jiang X, Zhao JJ, Jiang X. Correlation between hardness and elastic moduli of the covalent crystals. Comput Mater Sci 2011, 50: 2287-2290.

[63] Frantsevich IN, Voronov FF, Bokuta SA. Elastic constants and elastic moduli of metals and insulators. Naukova Dumka, Kiev, 1983.

[64] Yadav DS, Verma J, Singh DP. Elastic properties of rock-salt structured transition metal carbides. Journal of Pure Applied and Industrial Physics 2016, 6 212-220.

[65] Brown HL, Kempter CP. Elastic properties of zirconium carbide. Phys stat so/ 1996, 18: K21. 
[66] Yang Y, Wang W, Gan GY, et al. Structural, mechanical and electronic properties of (TaNbHfTiZr)C high entropy carbide under pressure: Ab initio investigation. Physica B: Condensed Matter 2018, 550 163-170.

[67] Feng L, Fahrenholtz WG, Hilmas GE, et al. Densification, microstructure, and mechanical properties of ZrC-SiC ceramics. J Am Ceram Soc 2019, 102: 5786-5795.

[68] Yate L, Coy LE, Aperador W. Robust tribo-mechanical and hot corrosion resistance of ultra-refractory Ta-Hf-C ternary alloy films. Sci Rep UK 2017, 7: 3080-3088.

[69] Valenccia DP, Yate L, Aperador W, et al. High electrocatalytic response of ultra-refractory ternary alloys of Ta-Hf-C carbide toward hydrogen evolution reaction in acidic media. J Phys Chem C 2018, 122: 25433-25440.

[70] Silvestroni L, Pienti L, Guicciardi S, et al. Strength and toughness: The challenging case of TaC-based composites. Composites: Part B 2015, 72: 10-20.

[71] He LF, Bao YW, Wang JY, et al. Microstructure and mechanical and thermal properties of ternary carbides in Hf-Al-C system. Acta Mater 2009, 57: 2765-2774.

[72] Laverntyev AA, Gabrelian BV, Vorzhev VB, et al. Electronic structure of cubic $\mathrm{Hf}_{x} \mathrm{Ta}_{1-x} \mathrm{C}_{y}$ carbides from X-ray spectroscopy studies and cluster self-consistent calculations. J Alloys Compd 2008, 462: 4-10.

Figures

(a)

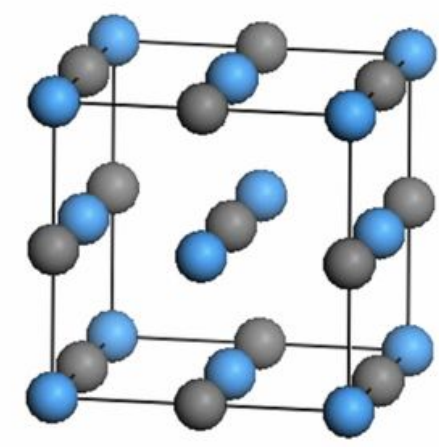

(b)

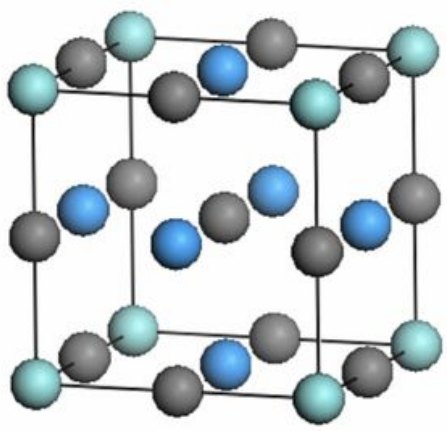

(c)

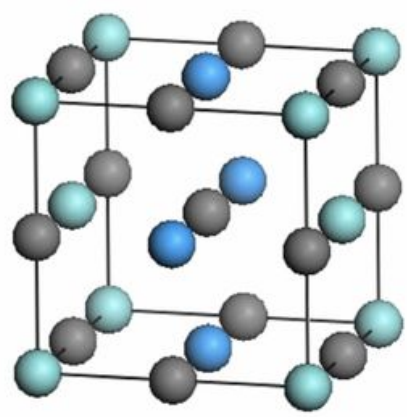

(e)

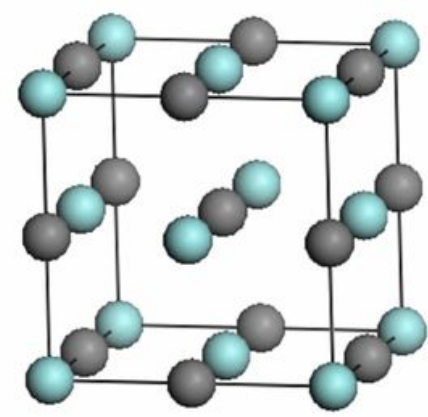

(e)
Ta

$\mathrm{Hf} / \mathrm{Zr}$

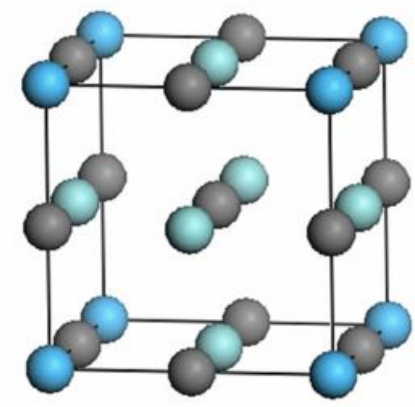


Figure 1

Crystal structures of pure TaC (a) and supercells of Ta1-xHfxC and Ta1-xZrxC for x=0.25 (b), 0.5(c), 0.75 (d), and 1 (e), respectively. Ta, C, and $\mathrm{Hf}$ or Zr atoms are represented by blue, gray, and green balls, respectively.

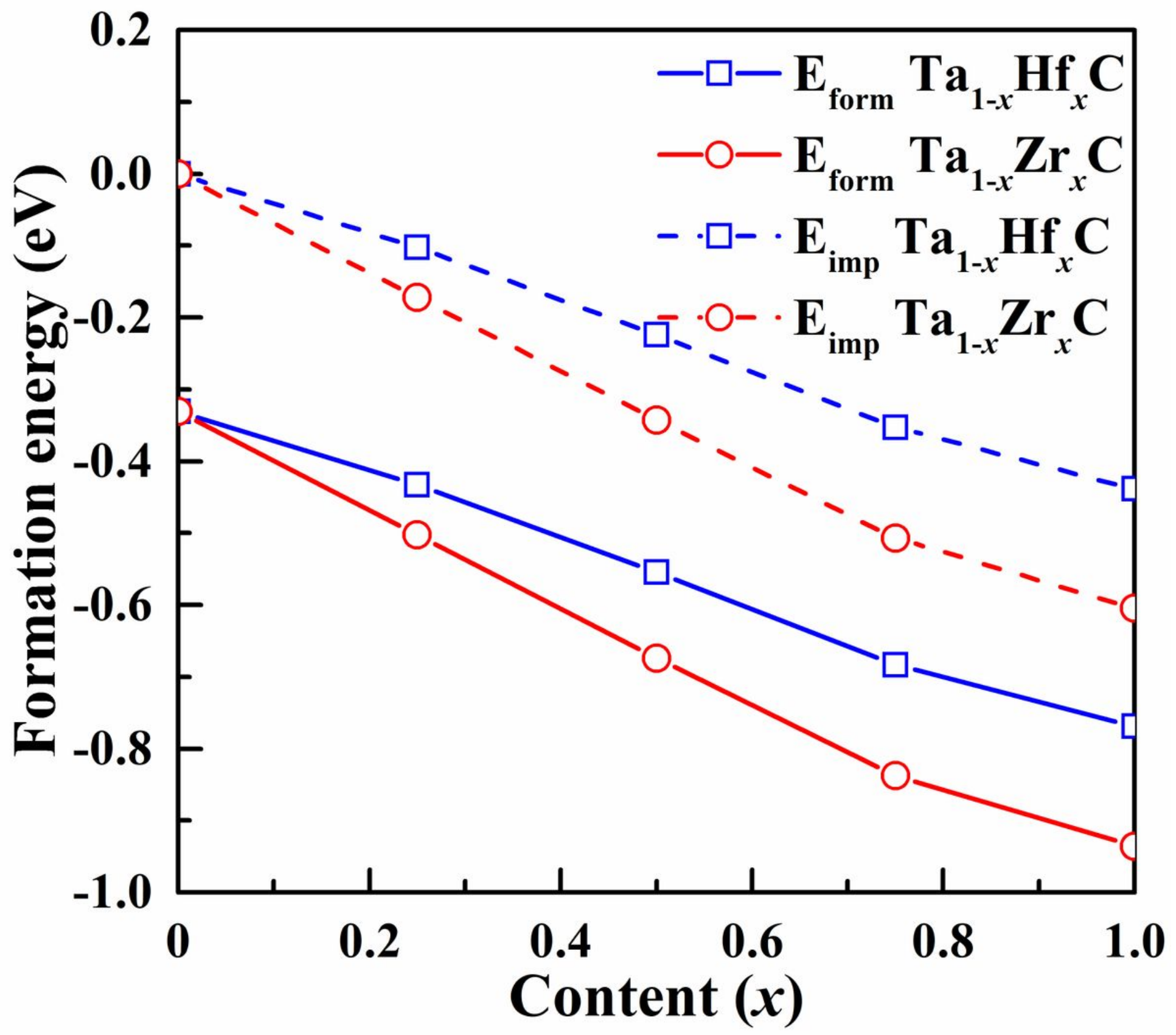

Figure 2

The formation energy (Eform) and impurity formation energy (Eimp) of Ta1-xHfxC and Ta1-xZrxC solid solution ceramics as a function of $\mathrm{Hf}$ or $\mathrm{Zr}$ content $\mathrm{x}$. 

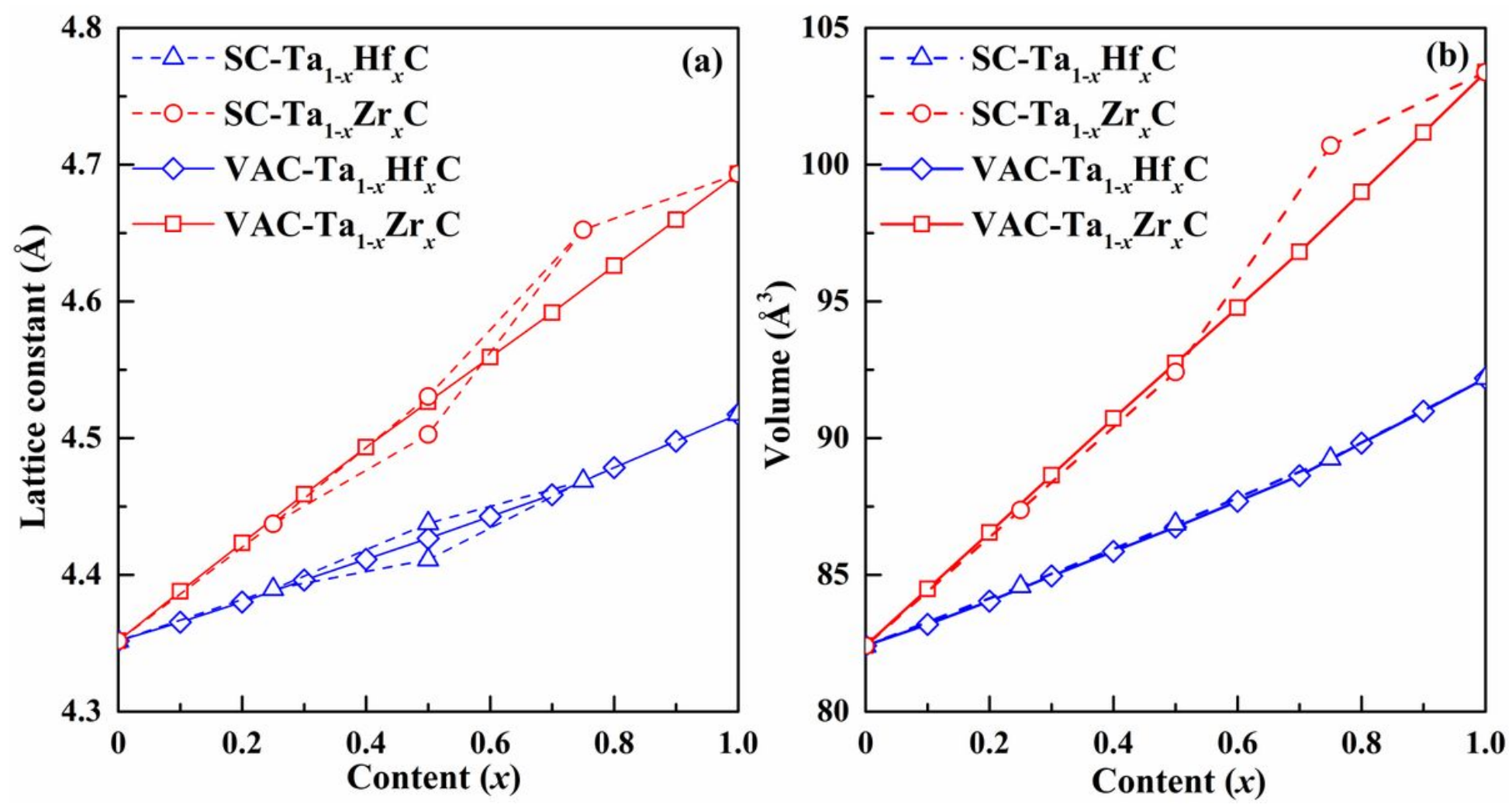

Figure 3

Comparison of the lattice constants (a) and volume (b) of the Ta1-xHfxC and Ta1-xZrxC solid solution ceramics as a function of $\mathrm{Hf}$ or $\mathrm{Zr}$ content $\mathrm{x}$ by supercell (SC) and virtual crystal approximation (VCA) methods. 


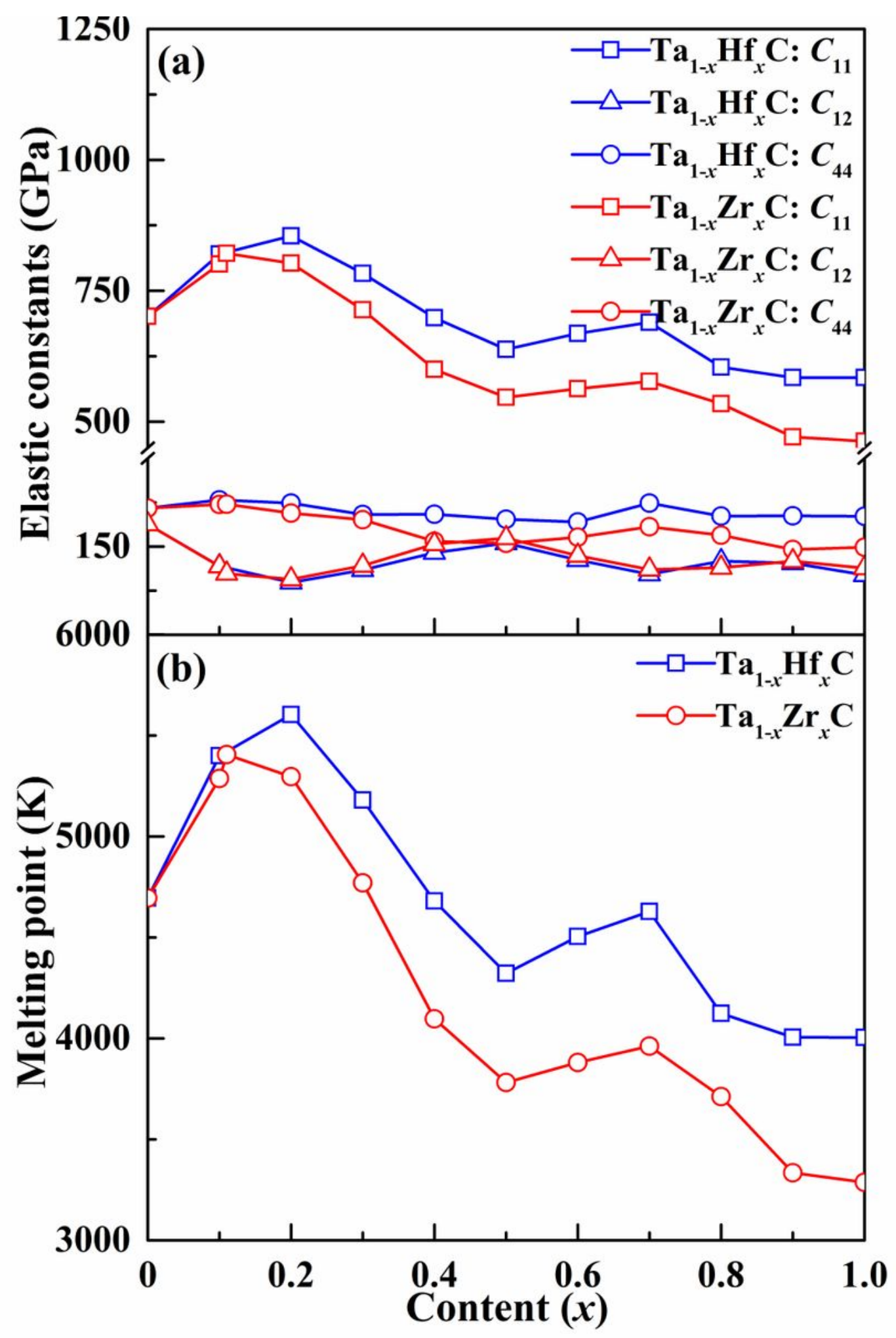

Figure 4

Calculated Elastic constants (a) and Melting points (b) for Ta1-xHfxC and Ta1-xZrxC solid solution ceramics as functions of $\mathrm{Hf}$ or $\mathrm{Zr}$ content $\mathrm{x}$. 

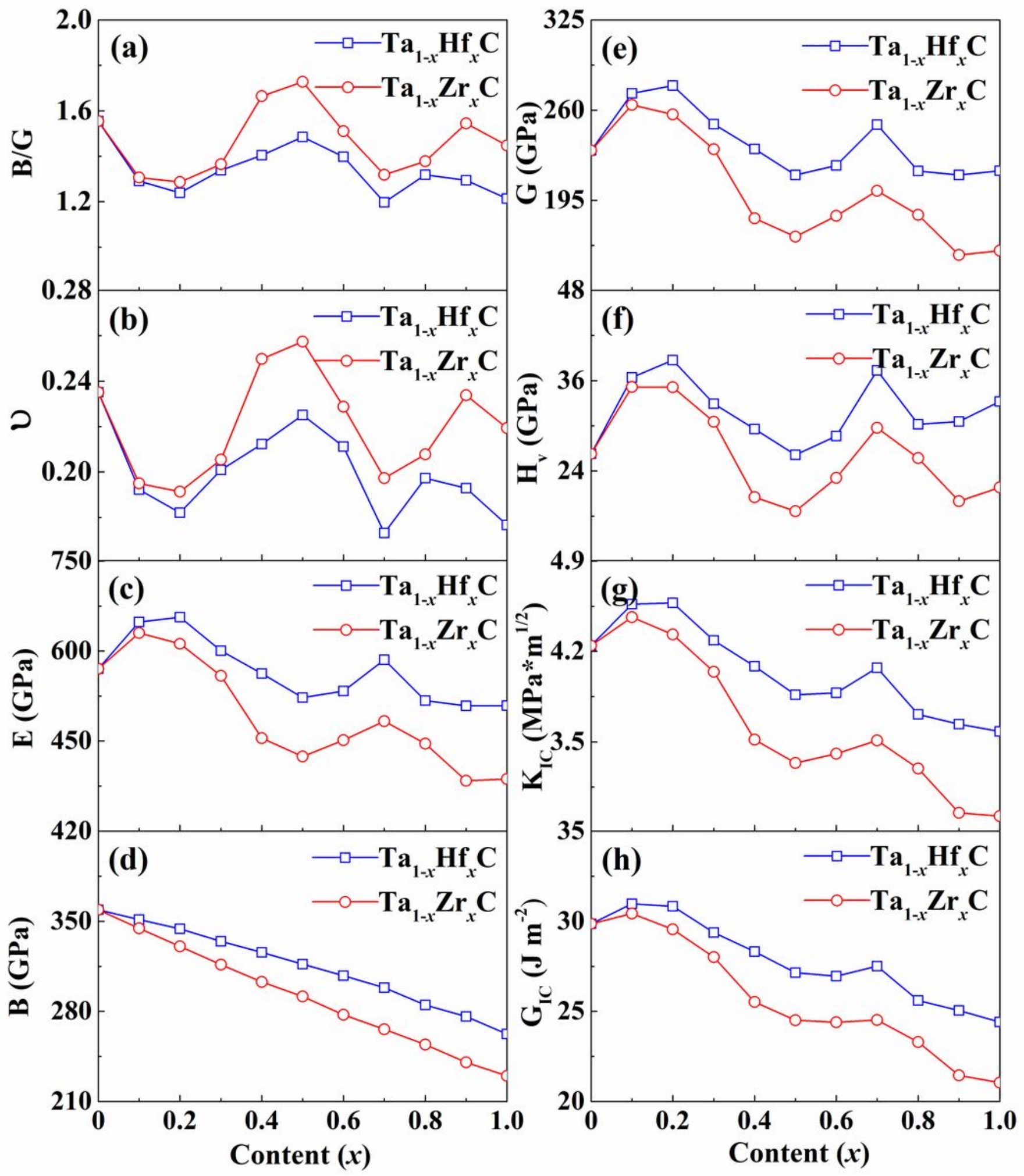

Figure 5

Calculated B/G ratio (a), Poisson's ratio (b), Young's modulus (c), bulk modulus (d), shear modulus (e), Vickers Hardness (f), fracture toughness (g) and critical energy release rate (h) for Ta1-xHfxC and Ta1$\mathrm{xZrxC}$ solid solution ceramics as a function of $\mathrm{Hf}$ or $\mathrm{Zr}$ content $\mathrm{x}$. 

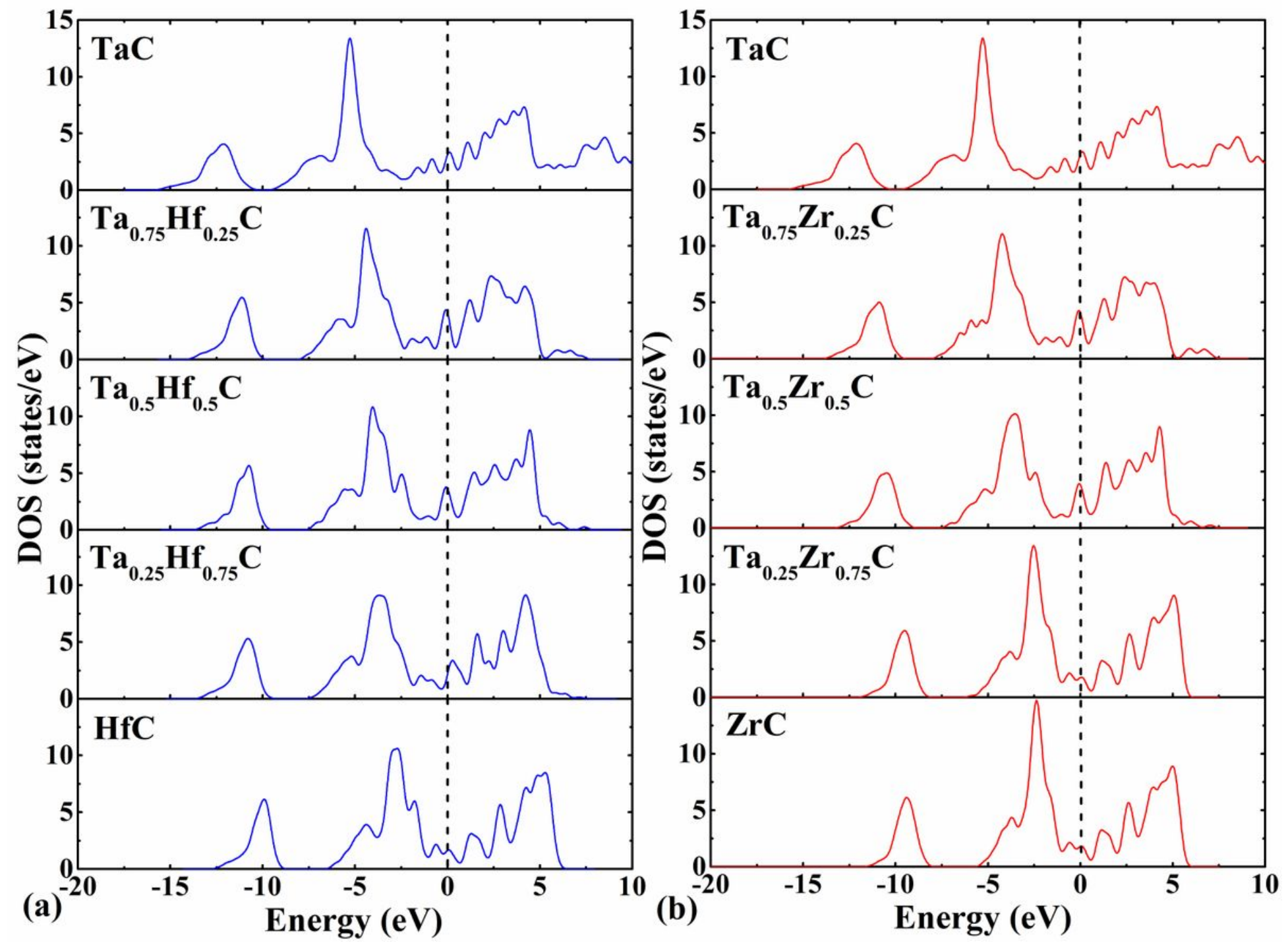

Figure 6

Electronic density of states of Hf-doped (a) and Zr-doped (b) TaC with different content. 